\title{
Stability of DNA in Dark-repair Mutants of Escherichia coli B Treated with Nalidixic Acid
}

\author{
By G. W. GRIGG \\ C.S.I.R.O., Division of Animal Genetics, P.O. Box 90, \\ Epping, New South Wales 212I, Australia
}

(Accepted for publication 5 December 1969)

\begin{abstract}
SUMMARY
Breakdown of DNA to acid-soluble fragments induced in strains of Escherichia coli B by nalidixic acid (Io $\mu \mathrm{g} . / \mathrm{ml}$.) differed in linear rate according to the ability of the strain to repair DNA lesions. Strains which were exr (BS-2) and exr, uvr (BS-I) exhibited excessive DNA breakdown following nalidixic acid treatment. The excision-defective $u v r$ strains, BS-8, BS-I2 and WWP-2 hcr, also degraded their DNA to acid-soluble fragments at a rate which initially was greater than that of the parental strain (E. coli B). This degradation was unaffected by the rad mutation. Removal of nalidixic acid from the system considerably lowered the rate of DNA breakdown. The responses to nalidixic acid and other agents potentiating DNA breakdown are compared.
\end{abstract}

\section{INTRODUCTION}

The antibiotic nalidixic acid selectively inhibits DNA synthesis in growing bacteria without impairing the synthesis of other macromolecules (Goss, Deitz \& Cook, 1964, 1965). Its deleterious effects on viability and on DNA synthesis require active growth and are absent in stationary phase cells. Nalidixic acid causes bacteria to grow as long snakes and to degrade portions of their DNA to acid-soluble fragments (Cook, Brown, Boyle \& Goss, 1966). A number of other treatments which impair DNA synthesis, such as u.v.- and x-irradiation, and the antibiotics Mitomycin $C$ and Phleomycin, also cause DNA breakdown. With these, the extent of the breakdown observed and its kinetics are influenced by the genotypes of the bacterial strains exposed to the treatments; mutants blocked in various steps of dark-repair processes varying widely from wild type in sensitivity to DNA breakdown.

In this paper the patterns of DNA breakdown in mutants blocked in either the ability to excise thymine dimers (UVR) or in a step in the recombinational-repair process (EXR, Witkin, I968; Rupp \& Howard-Flanders, I968), or in both (UVR, EXR), are compared with those of $E$. coli $\mathrm{B}$.

\section{METHODS}

The strains of bacteria used, together with their genotypes and source are shown in Table $\mathrm{I}$.

Thymine-requiring mutants of the strains listed in Table I were selected by the procedure of Okada, Yanagisawa \& Ryan (1960). The bacteria were radioactively labelled by growing them at $37^{\circ}$ with shaking in the glucose salts medium G.T. 
(Grigg, 1969), supplemented with $\left[{ }^{14} \mathrm{C}\right]$ thymidine $\left(20 \mu \mathrm{g} . / \mathrm{ml}\right.$.), overnight. The ${ }^{14} \mathrm{C}$ labelled organisms were washed and transferred to fresh medium containing nonradioactive thymidine and allowed to divide once before being used as exponentially growing cells in the experiments. The bacterial concentration at this stage was about $2 \times 10^{7} / \mathrm{ml}$. In determining the proportion of DNA degraded to acid-soluble fragments the procedure of Aoki, Boyce \& Howard-Flanders (1966) was followed. Nalidixic acid was bought from Sterling, Winthrop. Unless otherwise specified it was used at a concentration of $10 \mu \mathrm{g} . / \mathrm{ml}$.

\section{Table I. Repair deficient mutants of Escherichia coli used in this investigation}

\begin{tabular}{|c|c|c|c|}
\hline Strain & Source & Genotype & Reference \\
\hline B & R. Hill & lon & \\
\hline BS-I & R. Hill & lon, uvr, exr & $\begin{array}{l}\text { Mattern, Zwenk \& } \\
\text { Rörsch (1966) }\end{array}$ \\
\hline BS-2 & R. Hill & $l o n, e x$ & \\
\hline BS-8 & R. Hill & lon, uvrB, rad & $\begin{array}{l}\text { Donch \& Greenberg } \\
\text { (I968) }\end{array}$ \\
\hline $\begin{array}{l}\text { BS-12 } \\
\text { WWP-2 her }\end{array}$ & $\begin{array}{l}\text { R. Hill } \\
\text { R. Hill } \\
\text { ex E. Witkin }\end{array}$ & $\begin{array}{l}\text { lon, } u v r-12 \\
\text { lon, } u v r \mathrm{~A}, \mathrm{rad}, \mathrm{trp}\end{array}$ & $\begin{array}{l}\text { (Greenberg, private } \\
\text { communication) }\end{array}$ \\
\hline
\end{tabular}

\section{RESULTS}

DNA breakdown in all the bacterial populations studied commenced about $15 \mathrm{~min}$. after addition of nalidixic acid and proceeded at a linear rate for at least $2 \mathrm{hr}$.

The highest rate of degradation of DNA to acid-soluble fragments was observed in the two exr strains BS-2 and BS-I (Fig. I). The latter also carries the uvr mutation but its response to nalidixic acid-induced breakdown of DNA was identical to that of the $u v r^{+}$exr mutant BS-2. $50 \%$ of the DNA of BS-I and BS-2 bacteria was degraded in $3 \mathrm{hr}$. The corresponding figure for strain B bacteria was $17 \%$.

The pattern of DNA breakdown in the three $u v r e x r^{+}$strains, BS-8, BS-I2 and wwP-2 hcr, was identical and was not affected by the presence of the rad mutation. Initially the rate of breakdown in cultures of $u v r$ mutants was appreciably higher than in strain B cultures, but the rate dropped suddenly after $2 \mathrm{hr}$. After $3 \mathrm{hr}$ the proportion of DNA degraded to small fragments was rather similar to that of E. coli B (Fig. I).

Goss et al. (1965) reported that the inhibitory effects of nalidixic acid on DNA synthesis are rapidly reversed by washing cells free of the drug. Both the rate of DNA breakdown and the proportion of DNA degraded decreased immediately upon removal of nalidixic acid. This is illustrated (Fig. 2) by the observations on a culture of BS-I (uvr, exr) exposed for varying periods to nalidixic acid. The rate of DNA breakdown did not fall to zero upon removing the drug from the bacteria by Millipore filtration but continued at a lower rate for the $4 \mathrm{hr}$ period of the experiment.

\section{DISCUSSION}

DNA breakdown induced by treatments which themselves do not cause direct strand breakage or do so with low efficiency, e.g. u.v.-irradiation or Phleomycin ( $2 \mu \mathrm{g} . / \mathrm{ml}$.), is often reduced in $u v r$ mutants compared with $u v r^{+}$strains. This has led 
to the suggestion that since the first step in the excision of lesions, such as u.v.-induced pyrimidine dimers (Setlow \& Carrier, 1964), from DNA, involves an endonuclease mediated DNA chain break, the $u v r$ mutants which display reduced DNA breakdown are defective in this endonuclease. Certainly they exhibit fewer chain breaks following u.v.-irradiation (Setlow, Carrier \& Williams, 1967). That the rate of DNA breakdown induced by nalidixic acid in $u v r$ mutants exceeded that in $u v r^{+}$bacteria is therefore unusual.

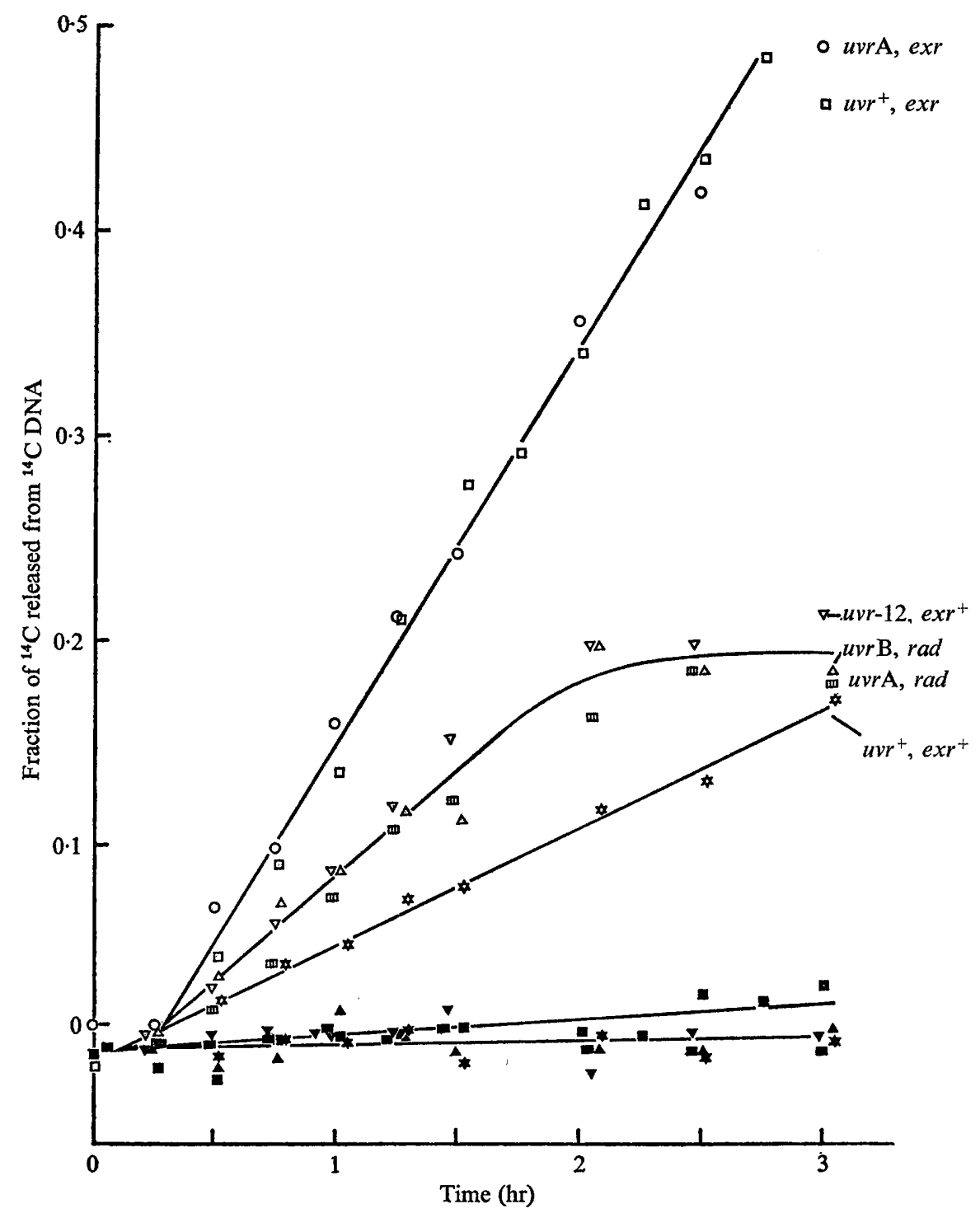

Fig. I. Effect of genotype on nalidixic acid-induced breakdown of DNA to acid-soluble fragments. Nalidixic acid (10 $\mu \mathrm{g} . / \mathrm{ml}$.) was present during the whole of the sampling period (open symbols). The following strains of $E$. coli B were used: exr, BS-2; exr uvrA, BS-I;

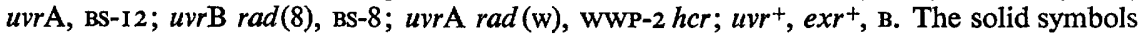
represent untreated controls. 
Ionizing radiations differ from the other treatments in that they induce an identical amount of DNA breakdown in $u v r$ and $u v r^{+}$cells. The excessive DNA breakdown induced by nalidixic acid in the exr mutant BS-2 followed the same pattern as that of other treatments causing breakdown and had the same kinetics in the $u v r$ exr mutant BS-I (cf. Suzuki, Moriguchi \& Horii (1966) after u.v. irradiation).

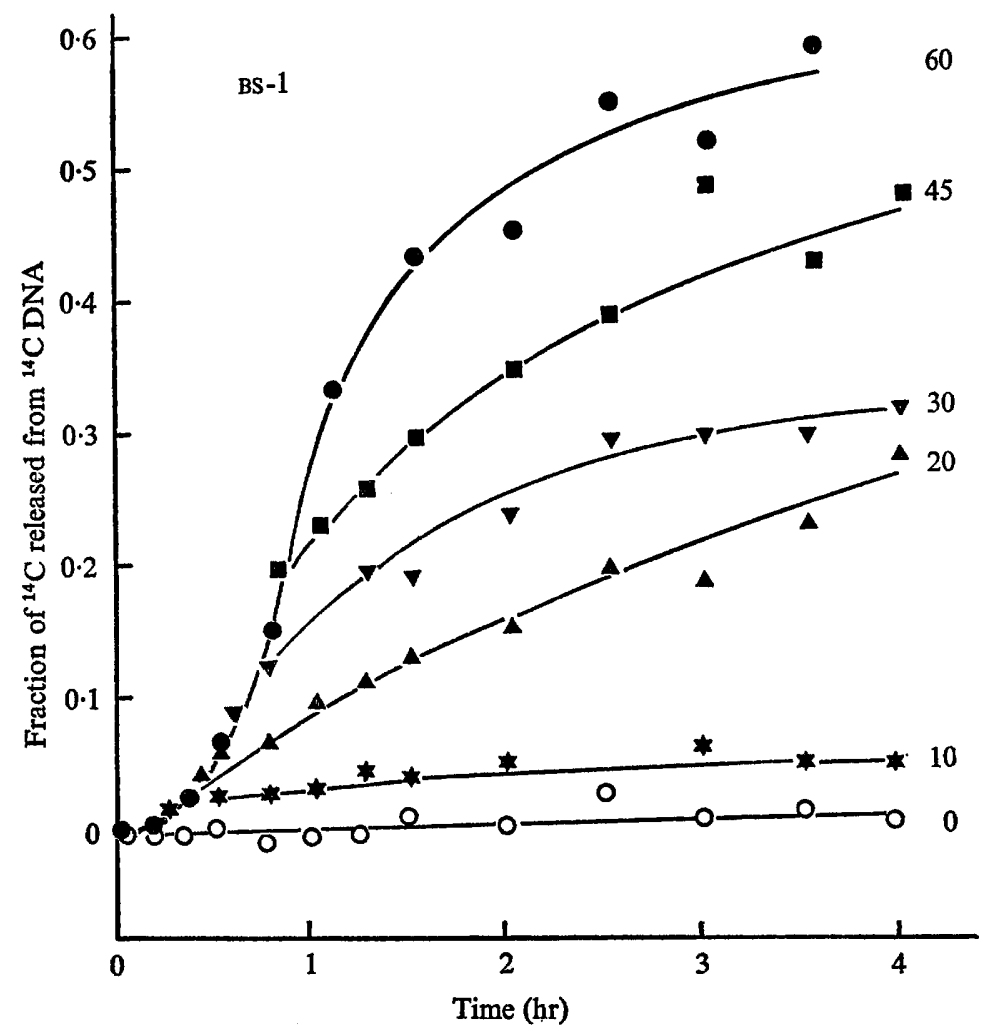

Fig. 2. Relation between period of exposure to nalidixic acid and DNA breakdown in $E$. coli BS-I thy cells. An exponentially growing culture whose DNA was previously labelled with $\left[{ }^{14} \mathrm{C}\right]$ thymidine was exposed to nalidixic acid $(\mathrm{ro} \mu \mathrm{g} . / \mathrm{ml}$.) at time 0 . After periods of $10,20,30,45$ and $60 \mathrm{~min}$. portions of the bacterial population were withdrawn from the nalidixic acid + GT + thymine medium, membrane filtered and resuspended in GT + thymine medium. The DNA breakdown observed in the several portions is expressed as a function of incubation time. The numerals adjacent to the curves indicate period of exposure to the nalidixic acid in $\mathrm{min}$.

The close association of ability of bacteria to repair u.v.-induced lesions in the dark and DNA breakdown, has been commented on before (see e.g. Howard-Flanders \& Boyce, I966; G. W. Grigg, N. Powles \& J. Smith, unpublished). It may be significant that of the several methods available of selectively inhibiting DNA synthesis temporarily or permanently, most, including thymine starvation, u.v. and x-irradiation, treatment with Mitomycin, Phleomycin or nalidixic acid, result also in DNA breakdown. Models to account for this correlation (Grigg, I968; G. W. Grigg, N. Powles \& J. Smith, unpublished) predict that any genetic or environmental impairment of repair synthesis or of the reaction rejoining disparate ends at chainbreaks would result 
in enhanced attack at unprotected break points by degradative enzymes and the release of acid-soluble fragments from the DNA. As a consequence of this depolymerization single strand nicks would be converted into double strand (chromosome) breaks. DNA breakdown by nalidixic acid may occur by a similar mechanism.

I am greatly indebted to Mrs Jennifer Smith for her very capable assistance with this project.

\section{REFERENCES}

Aoki, S., Boyce, R. P. \& Howard-Flanders, P. (1966). Sensitization of Escherichia coli to radiation by bromouracil: Excessive post-irradiation breakdown of DNA without concomitant synthesis. Nature 209, 686.

Cook, T. M., Brown, K. G., Boyle, J. V. \& Goss, W. A. (I966). Bactericidal action of nalidixic acid on Bacillus subtilis. Journal of Bacteriology 92, 15 Io.

DONCH, J. \& GREENBERG, J. (1968). Genetic studies of strain $\mathbf{B}_{s-8}$ of Escherichia coli. Genetical Research 2, 55.

Goss, W. A., DeITZ, W. H. \& Cook, T. M. (1964). Mechanism of action of nalidixic acid on Escherichia coli. Journal of Bacteriology 88, 1112.

Goss, W. A., DeITz, W. H. \& CooK, T. M. (1965). Mechanism of action of nalidixic acid on Escherichia coli. II. Inhibition of desoxyribonucleic acid synthesis. Journal of Bacteriology 92, 1068.

GriGG, G. W. (1968). Caffeine-death and a theory of chromosome breakage: An excision-repair suicide model. In Replication and Recombination of Genetic Material. Canberra: Australian Academy of Science.

GRIGG, G. W. (1969). Induction of DNA breakdown and death in Escherichia coli by phleomycin. Its association with dark-repair processes. Molecular and General Genetics 104, I.

HowARD-FLANDERS, P. \& BOYCE, R. P. (1966). DNA repair and genetic recombination. Studies on mutants of Escherichia coli defective in these processes. Radiation Research, Suppl. 6, 156.

MATTERN, I. E., ZWENK, H. \& RöRSCH, A. (I966). The genetic constitution of the radiation sensitive mutant Escherichia coli $\mathrm{B}_{s-8}$. Mutation Research 3, 374.

OKaDA, F. J., YANAGISAWA, K. \& RYAN, F. J. (1960). Elective production of thymineless mutants. Nature 188, 340.

RUPP, W. D. \& HowARd-Flanders, P. (1968). Discontinuities in the DNA synthesised in an excisiondefective strain of Escherichia coli following ultraviolet radiation. Journal of Molecular Biology 3r, 29 I.

SETLOW, R. \& CARRIER, W. L. (1964). The disappearance of thymine dimers from DNA: an error correcting mechanism. Proceedings of the National Academy of Sciences of the United States of America 5I, 226.

Setlow, R. B., CARRIER, W. \& Williams, R. (1967). Strand breaks during excision of pyrimidine dimers in vivo. Abstracts. Biophysics U.S TG-2, p. 83.

SUzukI, K., MoRIGUCHI, F. \& HoRII, Z. (1966). Stability of DNA in Escherichia coli B/R and BS-I irradiated with ultraviolet light. Nature 212, 1265.

WrTKIN, E. M. (1968). The role of DNA repair and recombination in mutagenesis. In Proceedings of the XIIth International Congress of Genetics, Tokyo. 